\title{
Antiulcer Effects of Methanol Extract of Euphorbia hirta and Honey Combination in Rats
}

\author{
Ifeanyi P. Onyeka $\mathbb{D}^{1}$ Sunday P. Bako, ${ }^{2}$ Mohammed M. Suleiman, ${ }^{3}$ \\ Felix Afamefula Onyegbule, ${ }^{4}$ Ugonna C. Morikwe, ${ }^{5}$ and Cyril Onyeka Ogbue ${ }^{1}$ \\ ${ }^{1}$ Department of Pharmacognosy and Traditional Medicine, Faculty of Pharmaceutical Sciences, Nnamdi Azikiwe University, \\ Awka, Nigeria \\ ${ }^{2}$ Department of Veterinary Pharmacology and Toxicology, Faculty of Veterinary Medicine, Ahmadu Bello University, Zaria, Nigeria \\ ${ }^{3}$ Department of Biological Sciences, Faculty of Science, Ahmadu Bello University, Zaria, Nigeria \\ ${ }^{4}$ Department of Pharmaceutical and Medicinal Chemistry, Faculty of Pharmaceutical Sciences, Nnamdi Azikiwe University, \\ Awka, Nigeria \\ ${ }^{5}$ Department of Pharmaceutical Microbiology and Biotechnology, Faculty of Pharmaceutical Sciences, Nnamdi Azikiwe University, \\ Awka, Nigeria
}

Correspondence should be addressed to Ifeanyi P. Onyeka; onyekaifeanyipeter@gmail.com

Received 6 April 2020; Revised 30 September 2020; Accepted 19 October 2020; Published 20 November 2020

Academic Editor: Emilia Lecuona

Copyright (c) 2020 Ifeanyi P. Onyeka et al. This is an open access article distributed under the Creative Commons Attribution License, which permits unrestricted use, distribution, and reproduction in any medium, provided the original work is properly cited.

\begin{abstract}
Stomach ulcer is an endemic gastrointestinal disorder which constitutes a major public health problem all over the world. Stomach ulcer results when there is an imbalance between the protective factors (mucus and bicarbonate) and aggressive factors (acid and pepsin) in the stomach. Dried powdered leaves and stem of the phytomedicine Euphorbia hirta (E. hirta) (1000 g) was extracted with methanol using a soxhlet apparatus. The evaluation of the phytochemical constituents of E. hirta and acute toxicity (to ascertain the safety of using the phytomedicine over a short period of time) was carried out. The antiulcer and gastroprotective effects of crude extract of $E$. hirta combined with honey in rats were evaluated. The study model using $0.6 \mathrm{M} \mathrm{HCl}$ model of ulceration was used to evaluate the antiulcer and gastroprotective activities of the phytomedicine. The soxhlet extraction of $E$. hirta gave a yield of $54.5 \mathrm{~g}$ of crude extract (5.45\%). Phytochemical screening of E. hirta showed that the extract contains alkaloids, tannins, saponins, glycosides, flavonoids, and unsaturated steroids. Acute toxicity studies showed that $\mathrm{LD}_{50}$ was greater than $5000 \mathrm{mg} / \mathrm{kg}$. The study showed that the crude extract of E. hirta at $200 \mathrm{mg} / \mathrm{kg}$ when administered alone had $54 \%$ inhibition of ulceration while when administered together with honey increased to $94 \%$ inhibition of ulceration, but honey alone had $89.47 \%$ inhibition of ulceration. This implied that $E$. hirta when combined with honey had a synergistic effect and enhanced the inhibition of ulceration, and this could be seen by the protection of the gastric mucosa. The study of the phytomedicine $E$. hirta combined with honey revealed that the phytomedicine has antiulcer activities against $0.6 \mathrm{M} \mathrm{HCl}$-induced gastric ulcer in rats. This therefore validates usage and claim by the Igbo people of the southeastern part of Nigeria that the phytomedicine of $E$. hirta combined with honey has good antiulcer potential.
\end{abstract}

\section{Introduction}

Stomach ulcer is an endemic gastrointestinal disorder which constitutes a major public health problem all over the world. Gastric ulcer occurs when there is a lack of balance between aggressive factors like the acid, pepsin, and local mucosal defense factors such as bicarbonate, mucus secretion, and synthesis of prostaglandins [1].
Gastric ulcer is characterized by the circumscription and complete loss of the gut epithelium in some parts of the digestive tract exposed to hypersecretion of hydrochloric acid and pepsin [2]. Treatment of ulcer has faced certain drawbacks such as unavailability of the drugs especially for rural dwellers, high cost of the conventional drugs, toxic effect of the conventional drugs, and ineffectiveness of the drugs. 
Herbal medicine is a new area that could provide alternative for the treatment of the ulcer disorder. These herbal drugs are highly acceptable, accessible, cheap, readily available, highly potent, and relatively safe. In the southeastern part of Nigeria, the Euphorbia hirta (E. hirta) plant is called "iruru agwo" (i.e., snake weed) and is locally used for the treatment of snakebite and wounds. It belongs to the genus Euphorbia, family Euphorbiaceae. It is characterized by the presence of white milky latex [3]. It is usually erect, slender-stemmed, and spreads up to $80 \mathrm{~cm}$ tall (although sometimes it is seen lying down) [4]. It is an annual broadleaved herb that has a hairy stem with many branches from the base to the top. The leaves are opposite, elliptical, oblong, or oblong-lanceolate, with a faintly tooted margin.

Studies had revealed that E. hirta has antibacterial [5], antihelmintic, antiretroviral [6], antiplasmodial, antiamoebic [7], antioxidant [8], sedative, antispasmodic, antifungal [9], and antimalaria [4] activities. The plant has been reported to contain alkaloids, triterpenoids, phytosterols, tannins, polyphenols, and flavonoids [3]. It is among the group of popular herbs used traditionally for the treatment of various diseases such as intestinal parasites, diarrhoea, peptic ulcers, heartburn, vomiting, amoebic dysentery, asthma, bronchitis, hay fever, laryngeal spasms, emphysema, coughs, colds, kidney stones, menstrual problems, sterility, and venereal diseases [4].

Honey, though it has been used as a vehicle in Ayurvedic medicine, has been reported to have antibiotic and wound healing effect [10] and also used for healing of cut and burns [11]. Also, the antimicrobial property of honey has been reported [12]. Honey has been viewed as a by-product of flower nectar and the upper aerodigestive tract of the honey bee; it is concentrated through a dehydration process inside the bee hive. The biological activity of honey is majorly determined by the biological sources of the nectar used by bees in the processing of honey. Plant-based drugs and other plant-based combination therapies have been viewed to be a potential source that is relatively clean and effectively safe as drugs, though not fully tapped. Mahmood et al. reported the antiulcer potential of honey combination with Trigonella foenum-graecum seed extract on experimental gastric ulcer in rats [13].

The choice of this present study was influenced by the folkloric claim by the Igbo people of Southeastern Nigeria that E. hirta combined with honey cures ulcer. Moreover, no scientific research work has been done concerning the antiulcer potential and the toxicity of the E. hirta combined with honey. The present study was undertaken to evaluate the acute toxicity, the preventive antiulcerogenic gastrotherapeutic potential of E. hirta combined with honey, and the phytochemical constituents of E. hirta.

\section{Materials and Methods}

2.1. Plant Material (Collection and Preparation). Fresh whole plant (leaves and the stem) of E. hirta were collected from the main campus of Ahmadu Bello University, Zaria, Kaduna state, Nigeria. The plant was identified at the herbarium, Department of Biological Sciences, A.B.U. Zaria. A voucher specimen number 583 was deposited. The plant materials (leaf and stem) were air dried at room temperature 10-14 days during the dry weather condition. The air-dried plant was ground, and $1000 \mathrm{~g}$ of the powder was extracted using $5000 \mathrm{ml}$ of $70 \%$ methanol by continuous extraction in a Soxhlet apparatus. The extract was concentrated to dryness. The concentrated extract was scrapped into a sample bottle and kept in desiccators until required.

2.2. Honey Collection. Honey used in the study was pure, unprocessed, unboiled, multifloral apiary honey from Apis mellifera Adansonni. The honey was collected from Forest Research Institute of Nigeria, Kaduna out-station, Kaduna state.

2.3. Animals. Healthy adult albino Wistar (63) rats (male) weighing between 150 and 170 were obtained from the Department of Veterinary Pharmacology and Toxicology, Ahmadu Bello University, Zaria. The animals were maintained at room temperature and humidity $\left(25^{\circ} \mathrm{C}, 70 \%\right.$ relative humidity) and allowed to acclimatize for 2 weeks. All the animals were fed with standard pelleted diet and water ad libitum. The study followed ethical guideline for investigations using experimental animals established by [14].

2.4. Other Materials. Cytotec ${ }^{\circledR}$ oral tablet manufactured by Pfizer Pharmaceuticals Ltd. was used. It contains $200 \mathrm{mcg}$ of misoprostol, a synthetic prostaglandin E1 analog [15]. Misoprostol Cytotec is a water-soluble tablet. Pharmacodynamics of misoprostol has shown both antisecretory (inhibiting gastric acid secretion) and mucosal protective properties in animals [15]. Misoprostol can increase bicarbonate and mucus production [15]. Misoprostol was administered at $50 \mu \mathrm{g} / \mathrm{kg}$. The plant extract and honey combination was dissolved at $250 \mathrm{mg} / \mathrm{ml}$ of honey as stock concentrations.

Jenway spectrophotometer model 6405UV/VIS with serial number 3948, by Barloworld Scientific Limited (DUNMOW. ESSEX., CM63LB) was used.

2.5. Phytochemical Screening. Phytochemical analysis was conducted using the method described by [16] to determine the presence of secondary metabolites in E. hirta.

2.6. Acute Toxicity Study. Acute toxicity studies of the extract were made using the standard method of [17] slightly modified to ascertain the acute toxicity of the methanol extract of E. hirta. Briefly, nine animals (mice) were randomly allocated into 3 groups of 3 rats each. Animals in groups 1, 2 , and 3 were given 10,100 , and $1000 \mathrm{mg} / \mathrm{kg}$ body weights, respectively, of the extract through the oral route. Animals were therefore monitored for signs of toxicity and mortality for 2 days (48 hours). Signs of toxicity and pathological findings observed were recorded appropriately. All the animals survived, so the extract was further subjected to acute toxicity test with higher doses in the second trial. In the second trial, 4 animals were randomly allocated to 4 groups of one animal each. Animals in groups 1, 2, 3, and 4 were given 1200, 1600,2900 , and $5000 \mathrm{mg} / \mathrm{kg}$ body weight, respectively, of the extract. 
2.7. 0.6 M HCl Ulcer Model. Gastroprotective effect of crude methanol extract of E. hirta combined with honey was conducted as described by the method of [18]. Misoprostol was the standard drug used. Initially, the animals were fasted for 48 hours but were allowed free access to water ad libitum. They were randomly selected and divided into 9 groups of five rats each. Group 1 served as the negative control that received only water; group 2 served as the positive control that received misoprostol; groups 3 to 5 received the crude extract of E. hirta at doses of 200, 400, and $800 \mathrm{mg} / \mathrm{kg}$ body weight, respectively; groups 6 to 8 received a combination of $1 \mathrm{ml}$ honey and crude extract of E. hirta at doses 200, 400 , and $800 \mathrm{mg} / \mathrm{kg}$ combined with honey $(1 \mathrm{ml})$, while group 9 received only $1 \mathrm{ml}$ of honey. Thirty minutes after treatment, individual rats were given $0.6 \mathrm{M} \mathrm{HCl}(1 \mathrm{ml} / \mathrm{rat})$ orally as an ulcerogen. Three hours after treatment with $\mathrm{HCl}$, all the rats were sacrificed in a chloroform chamber. On each animal, ventral midline incision was made on the abdomen to expose the stomach. The ulcerated surfaces in each stomach were measured with transparent millimeter(mm-) scale ruler, and the result for each group was expressed in mm of mean ulcer index [19].

2.8. Gastric Mucus. The concentration of gastric mucus was determined using the method of [20]. The excised glandular portion of the stomach $(500 \mathrm{mg}$ ) was soaked in $0.1 \% \mathrm{w} / \mathrm{v}$ Alcian blue solution buffered with $0.05 \mathrm{M}$ sodium acetate and $\mathrm{HCl}$ for 2 hours. The excess dye or the uncomplexed dye was removed by rinsing the stomach tissue twice in $0.25 \mathrm{M}$ sucrose solution for 1 hour. The dye complexed with gastric wall mucus was extracted with $0.5 \mathrm{M} \mathrm{MgCl}_{2}$ for 2 hours. The extract was then shaken vigorously with an equal volume of diethyl ether, and the resulting blue emulsion was centrifuged at $5000 \mathrm{~g}$ for 10 minutes. The optical density of the solution was read against a buffer blank at $580 \mathrm{~nm}$ using a Jenway spectrophotometer, and the quantity of Alcian blue extract per gram wet stomach was then observed and noted.

2.9. Percentage Inhibition of Ulceration (PIU). The percentage inhibition of ulceration was expressed as a percentage of the control by using the following formula as described by [21]:

Inhibition percentage $(\%)=\left[\frac{\mathrm{UI}_{\mathrm{ulcer} \text { control }}-\mathrm{UI}_{\text {treated }}}{\mathrm{UI}_{\mathrm{ulcer} \text { control }}}\right] \times 100$.

2.10. Statistical Analysis. All statistical analyses were done using Graphical Prism version 4.0 for Windows from GraphPad software, San Diego, USA. Data obtained were analysed using one-way analysis of variance. Where significant differences were observed, the Turkey post hoc test was used to identify and compare differences between groups. Values were considered significant if $P<0.05$ and 0.01 . Duncan multiple range test was used to compare the means across each treatment group with untreated group.

\section{Results}

One thousand grams (1000 g) of E. hirta gave an average yield of $54.5 \mathrm{~g}$ of the extract, and this gave a percentage yield of $5.45 \%$ when extracted with the continuous extraction process of the Soxhlet apparatus.

3.1. Phytochemical Screening. The result of the phytochemical screening is presented in Table 1. Phytochemical screenings of E. hirta showed that the extract contains alkaloids, flavonoids, tannins, saponins, glycosides, and unsaturated steroids while triterpenes and anthraquinones were absent.

3.2. Acute Toxicity Studies. The result of the acute toxicity studies is presented in Table 2. It showed that the $\mathrm{LD}_{50}$ of E. hirta is above $5000 \mathrm{mg} / \mathrm{kg}$ of crude extract because no death was recorded above $5000 \mathrm{mg} / \mathrm{kg}$ in the rats [22].

3.3. Ulcer Index. The result of the ulcer index of rats is presented in Table 3 and Figure 1. The result showed that the rats pretreated with misoprostol, honey alone, E. hirta alone, and in combination with honey at doses of 200,400, and $800 \mathrm{mg} / \mathrm{kg}$ had a significantly reduced area of gastric ulcer formation compared to ulcer in the negative control group that received only normal saline. The result from examination of gross ulceration of the stomach showed that the negative control had the highest level of ulceration as indicated by the ulcer index followed by rats that received $400 \mathrm{mg} / \mathrm{kg}$, $800 \mathrm{mg} / \mathrm{kg}$, and $200 \mathrm{mg} / \mathrm{kg}$ of the crude extract of E. hirta respectively.

The result showed that rats that were pretreated with $200 \mathrm{mg} / \mathrm{kg}$ plus honey (1.4) combination had the least ulcer index followed by the rats that received misoprostol (standard drugs) (1.6), 400 (3.2), and $800 \mathrm{mg}$ (3.2) of extract combined with honey when compared to the rats that were pretreated with 200, 400, and $800 \mathrm{mg} / \mathrm{kg}$ of extract alone and the negative control group.

The result showed significant reduction of ulceration (ulcer index) among rats treated with $200 \mathrm{mg} / \mathrm{kg}$ of the leaf extract of M. oppositifolius combined with honey when compared with all other treatment regimen. No significant difference was observed between the rat group treated with $800 \mathrm{mg}$ plus honey and $400 \mathrm{mg}$ plus honey compared with the group that received only honey $(1 \mathrm{ml})$. Also, there was a statistical difference between the groups treated with honey $(1 \mathrm{ml})$ and the group treated with the leaf extract at 200,400, and $800 \mathrm{mg} / \mathrm{kg}$ alone. There was enhanced significant reduction in ulceration among the group treated with $200 \mathrm{mg}+$ honey when compared with honey alone $(1 \mathrm{ml})$ and when compared with 400 and $800 \mathrm{mg} / \mathrm{kg}$ plus honey. This implied that the crude leaf extract of $M$. oppositifolius at $200 \mathrm{mg}+$ honey combined had enhanced significant therapeutic effect against ulceration in rats. This implied that the combination of honey and E. hirta crude leaf extract at $200 \mathrm{mg}+$ honey showed significant synergistic effect in gross reduction of ulceration in $0.6 \mathrm{M}$ hydrochloric acid-induced ulcers in rats.

3.4. Percentage Inhibition of Ulceration. The result of the percentage inhibition of ulceration is presented in Table 3 and Figure 2 (Table 3 ). The result of percentage inhibition of 
TABLE 1: Phytoconstituents in the crude methanol extract of Euphorbia hirta.

\begin{tabular}{lc}
\hline Phytochemical compounds & Inference \\
\hline Alkaloids & Present \\
Tannins & Present \\
Saponins & Present \\
Glycosides & Present \\
Flavonoids & Present \\
Anthraquinones/free antracene & Absent \\
Unsaturated steroids & Present \\
Triterpenes & Absent \\
\hline
\end{tabular}

TABle 2: Acute toxicity test of methanol leaf extract of E. hirta.

\begin{tabular}{lccc}
\hline Phase & Dose $(\mathrm{mg} / \mathrm{kg})$ & No. of animals & Death ratio \\
\hline \multirow{3}{*}{ Phase 1} & 10 & 3 & $0 / 3$ \\
& 100 & 3 & $0 / 3$ \\
& 1000 & 3 & $0 / 3$ \\
\multirow{3}{*}{ Phase 2 } & 1200 & 1 & $0 / 1$ \\
& 1600 & 1 & $0 / 1$ \\
& 2900 & 1 & $0 / 1$ \\
& 5000 & 1 & $0 / 1$ \\
\hline
\end{tabular}

ulceration showed that rats pretreated with a combination of honey and E. hirta at $200 \mathrm{mg}$ (94.74\%) had the highest (significant) percentage inhibition of ulceration when compared with the rats pretreated with 200 (54.09\%), 400 (45.34\%), and $800 \mathrm{mg} / \mathrm{kg}(49.94 \%)$ of $E$. hirta alone and in $400(88 \%)$ and $800 \mathrm{mg}(88 \%)$ combinations with honey, respectively, while honey alone had $89.47 \%$ inhibition of ulceration, and this is significantly different. Also, the result clearly showed the synergy in percentage inhibition and antiulcer activity of the rats pretreated with $E$. hirta combination with honey when compared with those treated with only 200,400 , and $800 \mathrm{mg} / / \mathrm{kg}$ of $E$. hirta extract alone. This implied that crude extract of $E$. hirta when combined with honey had better inhibition of ulceration when compared with the crude extracts that were administered alone to the rats. Although no significant difference was seen between the group that received honey alone $(1 \mathrm{ml})$ when compared with the group that received E. hirta leaf extract at 400 and $800 \mathrm{mg} / \mathrm{kg}$, respectively, combined with honey. There is significant difference between the group that received $200 \mathrm{mg}$ E. hirta leaf extract plus honey when compared with the group that received honey alone $(1 \mathrm{ml})$ and groups that received extract at 400 and $800 \mathrm{mg} / \mathrm{kg}$ plus honey, respectively. This implied that $200 \mathrm{mg} / \mathrm{kg}$ of the leaf extract of E. hirta plus honey worked synergistically to inhibit ulceration. There is no statistical difference between the group treated with $200 \mathrm{mg} / \mathrm{kg}$ of the crude extract plus honey when compared with the standard drugs; hence, they have similar therapeutic effect.

3.5. Stomach Weight. The result of the effect of E. hirta when combined with honey on the stomach weight of rats is presented in Table 3 and Figure 3. The result showed that
TABle 3: Antiulcer effect of crude methanol extract of $E$. hirta combined with honey in rats.

\begin{tabular}{lcccc}
\hline Dosage & $\begin{array}{c}\text { Ulcer } \\
\text { index }\end{array}$ & $\begin{array}{c}\text { Stomach } \\
\text { weight }\end{array}$ & $\begin{array}{c}\text { Gastric } \\
\text { mucus }\end{array}$ & PIU \\
\hline $200 \mathrm{mg} / \mathrm{kg}$ & $12.24^{\mathrm{c}}$ & $1.29^{\mathrm{a}}$ & 0.034 & $54.09^{\mathrm{d}}$ \\
$400 \mathrm{mg} / \mathrm{kg}$ & $14.19^{\mathrm{e}}$ & $1.28^{\mathrm{a}}$ & 0.038 & $45.34^{\mathrm{b}}$ \\
$800 \mathrm{mg} / \mathrm{kg}$ & $13.25^{\mathrm{d}}$ & $1.28^{\mathrm{a}}$ & 0.035 & $48.94^{\mathrm{c}}$ \\
$\begin{array}{l}200 \mathrm{mg} / \mathrm{kg} \\
+ \text { honey }\end{array}$ & $1.4^{\mathrm{a}}$ & $1.29^{\mathrm{a}}$ & 0.052 & $94.74^{\mathrm{f}}$ \\
$\begin{array}{l}400 \mathrm{mg} / \mathrm{kg} \\
+ \text { honey }\end{array}$ & $3.2^{\mathrm{b}}$ & $1.28^{\mathrm{a}}$ & 0.048 & $87.97^{\mathrm{e}}$ \\
$\begin{array}{l}800 \mathrm{mg} / \mathrm{kg} \\
+ \text { honey }\end{array}$ & $3.2^{\mathrm{b}}$ & $1.28^{\mathrm{a}}$ & 0.035 & $87.97^{\mathrm{e}}$ \\
$\begin{array}{l}\text { Mis } 50 \mu \mathrm{gg} / \mathrm{kg} \\
\text { Honey (1 ml) }\end{array}$ & $1.6^{\mathrm{b}}$ & $1.31^{\mathrm{b}}$ & 0.035 & $93.99^{\mathrm{f}}$ \\
NS $5 \mathrm{ml} / \mathrm{kg}$ & $2.8^{\mathrm{b}}$ & $1.29^{\mathrm{a}}$ & 0.034 & $89.47^{\mathrm{e}}$ \\
\hline
\end{tabular}

NB: any two or more means having a common letter are not statistically different at the $5 \%$ level of significance.

there was no significant difference in the stomach weight of rats among the entire treatment group. This implies that the weight of the stomach of the rats does not depend on the treatments. The result showed that the rats pretreated with $200 \mathrm{mg} / \mathrm{kg}$ and $200 \mathrm{mg} / \mathrm{kg}$ combined with honey had $1.29 \mathrm{~g}$ of the stomach weight while those that received $400 \mathrm{mg}$ and $400 \mathrm{mg} / \mathrm{kg}$ combined with honey had $1.28 \mathrm{~g}$ of the stomach weight. The weight of the stomach of the rats pretreated with $800 \mathrm{mg} / \mathrm{kg}$ and $800 \mathrm{mg} / \mathrm{kg}$ combined with honey also was $1.28 \mathrm{~g}$ while honey alone had $1.29 \mathrm{~g}$ of stomach weight. The result further showed that misoprostol and distilled water had $1.31 \mathrm{~g}$ each of the stomach weight.

3.6. Gastric Mucus. The result of the effect of E. hirta on gastric mucus secretion on the stomach is presented in Table 3 and Figure 4 . The study showed that the honey combined with E. hirta at $200 \mathrm{mg} / \mathrm{kg}$ enhanced the gastric mucus secretion, though there was no significant difference with the other treatment groups. Rats administered with $200 \mathrm{mg} / \mathrm{kg}$ combined with honey had the highest concentration of gastric mucus $(0.052 \mu \mathrm{g})$ while the rats administered with $200 \mathrm{mg} / \mathrm{kg}$ of the crude extract alone had the least $0.034 \mu \mathrm{g}$ of gastric mucus concentration. The result showed that rats administered with $200 \mathrm{mg}$ alone had $0.034 \mu \mathrm{g}$ concentration of gastric mucus while the rat administered with $200 \mathrm{mg} / \mathrm{kg}$ combined with honey had $0.052034 \mu \mathrm{g}$ concentration of gastric mucus. This implied that honey combined with the crude extract of E. hirta had effect on the gastric mucus concentration which could be attributed to the cytoprotective nature of honey and the wound healing effect of honey which worked in synergy with crude extract of E. hirta to inhibit ulcers in rats.

\section{Discussion}

The present work evaluated the phytoconstituents, acute toxicity, and antiulcer effect of methanol extract of E. hirta combined with honey in rats. The result of phytochemical 


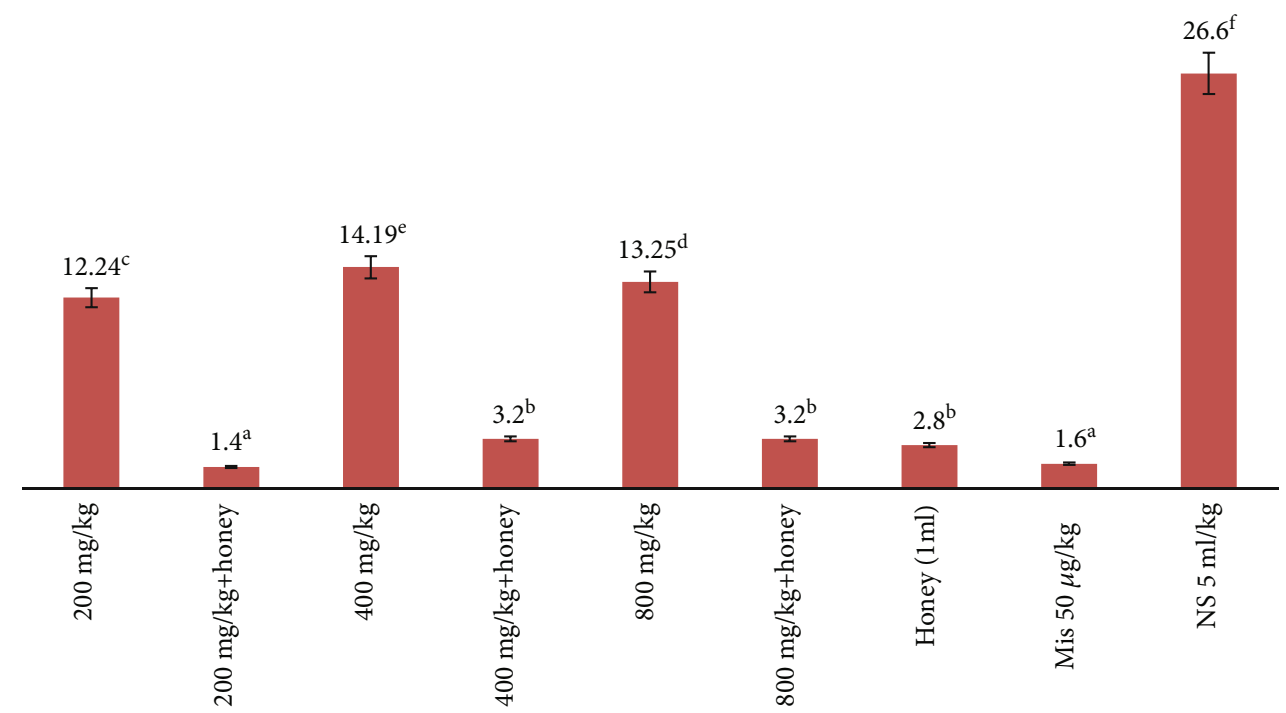

FIGURE 1: Effect of crude extract of $E$. hirta combined with honey on the ulcer index of rats using 0.6 M ulcer model. (NB: any two or more means having a common letter are not statistically different at the $5 \%$ level of significance.)

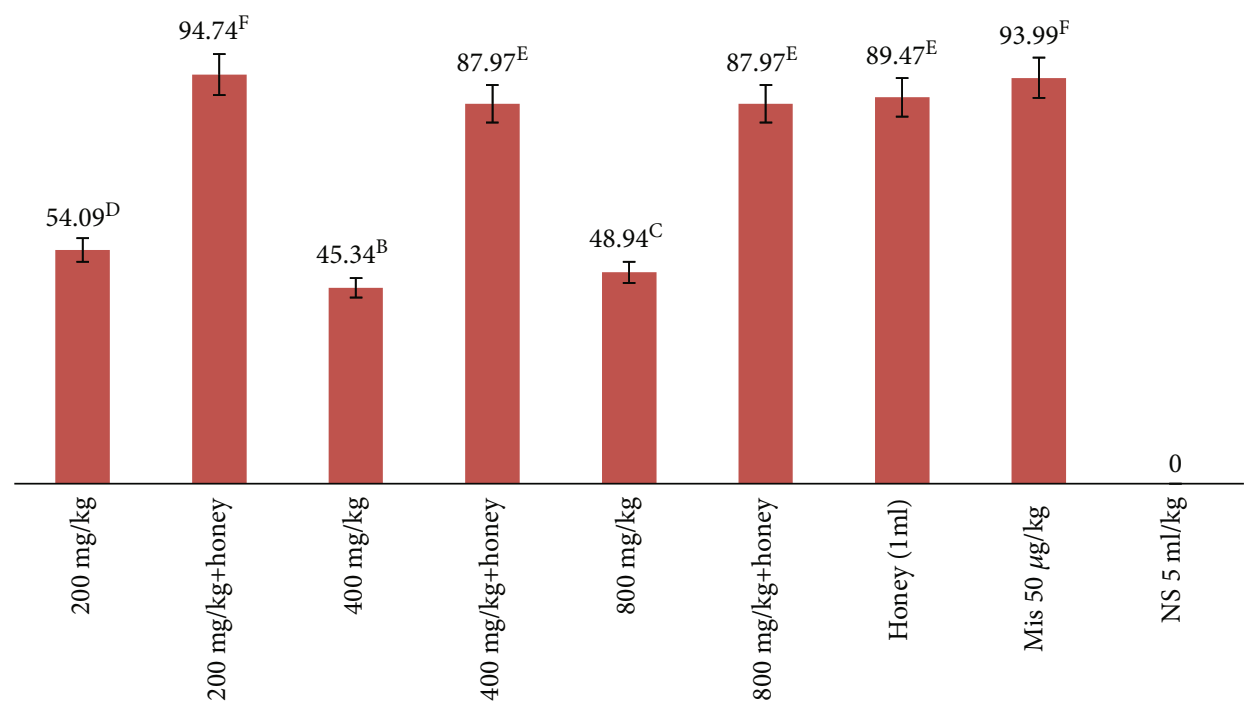

Figure 2: Percentage inhibition of ulceration of E. hirta combined with honey in $0.6 \mathrm{M} \mathrm{HCl}$ model ulceration in rats. (NB: any two or more means having a common letter are not statistically different at the $5 \%$ level of significance.)

screening of E. hirta revealed the presence of alkaloids, tannins, saponins, glycosides, flavonoids, and unsaturated steroids. This is in agreement with the findings of $[3,23$, 24] who reported similar phytoconstituents in E. hirta.

The result of the acute toxicity evaluation of $E$. hirta combined with honey showed no apparent toxic (mortality) effect in rats up to a dose of $5000 \mathrm{mg} / \mathrm{kg}$ when given orally. Therefore, $\mathrm{LD}_{50}$ of the extract combined with honey was considered to be above $5000 \mathrm{mg} / \mathrm{kg}$ of the extract [17]. This implies that the plant is a relative safe for consumption and is used in ethnomedicine, at doses not exceeding $5000 \mathrm{mg} / \mathrm{kg}$ of the extract.

Our choice of this combination therapy was informed by the traditional use of the leaves of $E$. hirta for the treatment of peptic ulcer in folk medicine and the well-established therapeutic values of honey, particularly in the treatment of gastrointestinal disorders. A combination therapy of the leaf extract and honey has an excellent antiulceration activity with a high potency.

The evaluation of antiulcerative effects of E. hirta combined with honey at doses of 200,400 , and $800 \mathrm{mg} / \mathrm{kg}$ using different ulcer models showed that the combination is effective. Gastric ulcer instillation using $0.6 \mathrm{~mol} / \mathrm{l} \mathrm{HCl}$ induces gastric necrotic damage due to infiltration of inflammatory cell leading to reduction in the secretion of bicarbonate, gastric mucus, and hypersecretion of nitric oxide. Instillation by $0.6 \mathrm{~mol} / \mathrm{l} \mathrm{HCl}$ reduces the gastric blood flow and induces the oxidative stress by increasing the production of malondialdehyde thereby reducing secretion of endogenous glutathione. The significant increase in the ulcer index gastric volume as observed in the negative group that received water after the instillation of ethanol confirmed the induction of ulcer, which can be attributed to either reactive oxygen species 


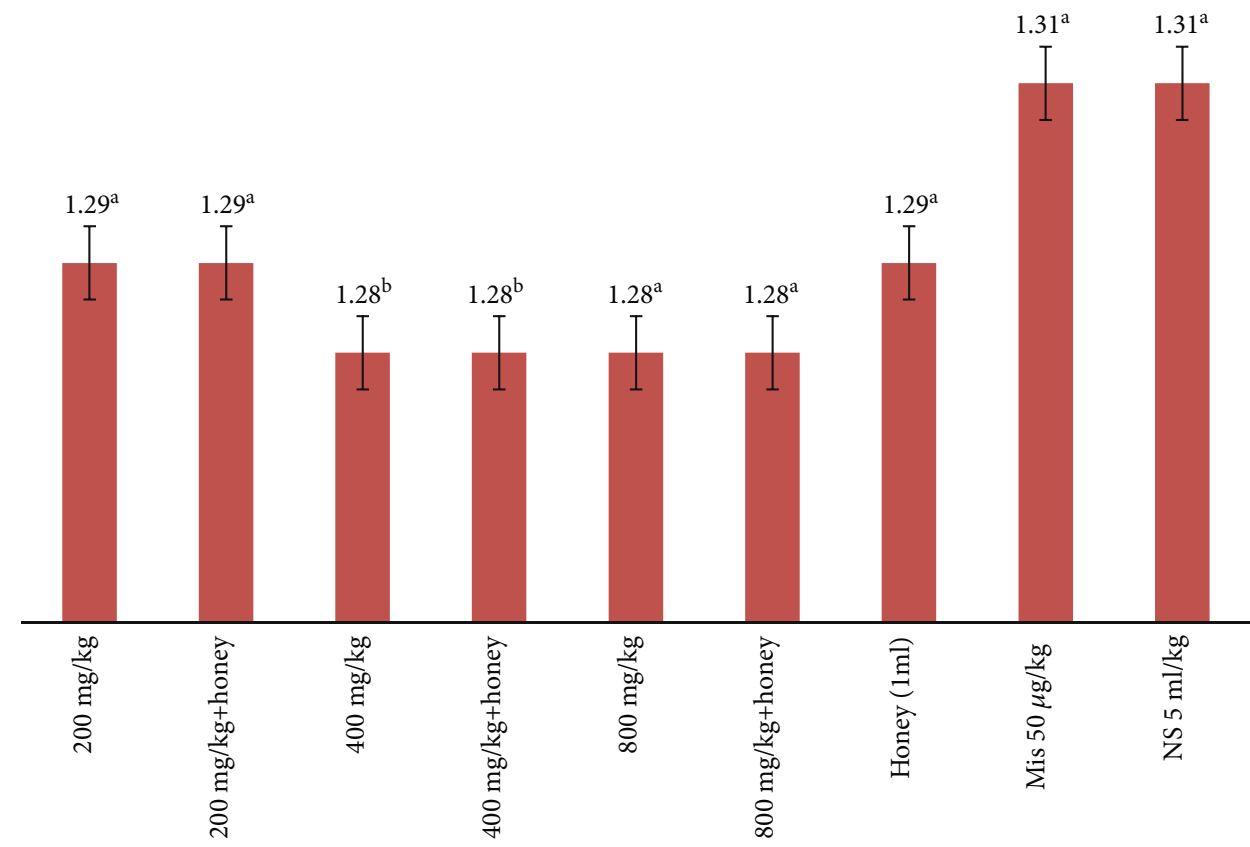

FIGURE 3: Effect of crude extract of E. hirta combined with honey on the stomach weight of rats using $0.6 \mathrm{M} \mathrm{HCl}$ (NB: any two or more means having a common letter are not statistically different at the $5 \%$ level of significance.)

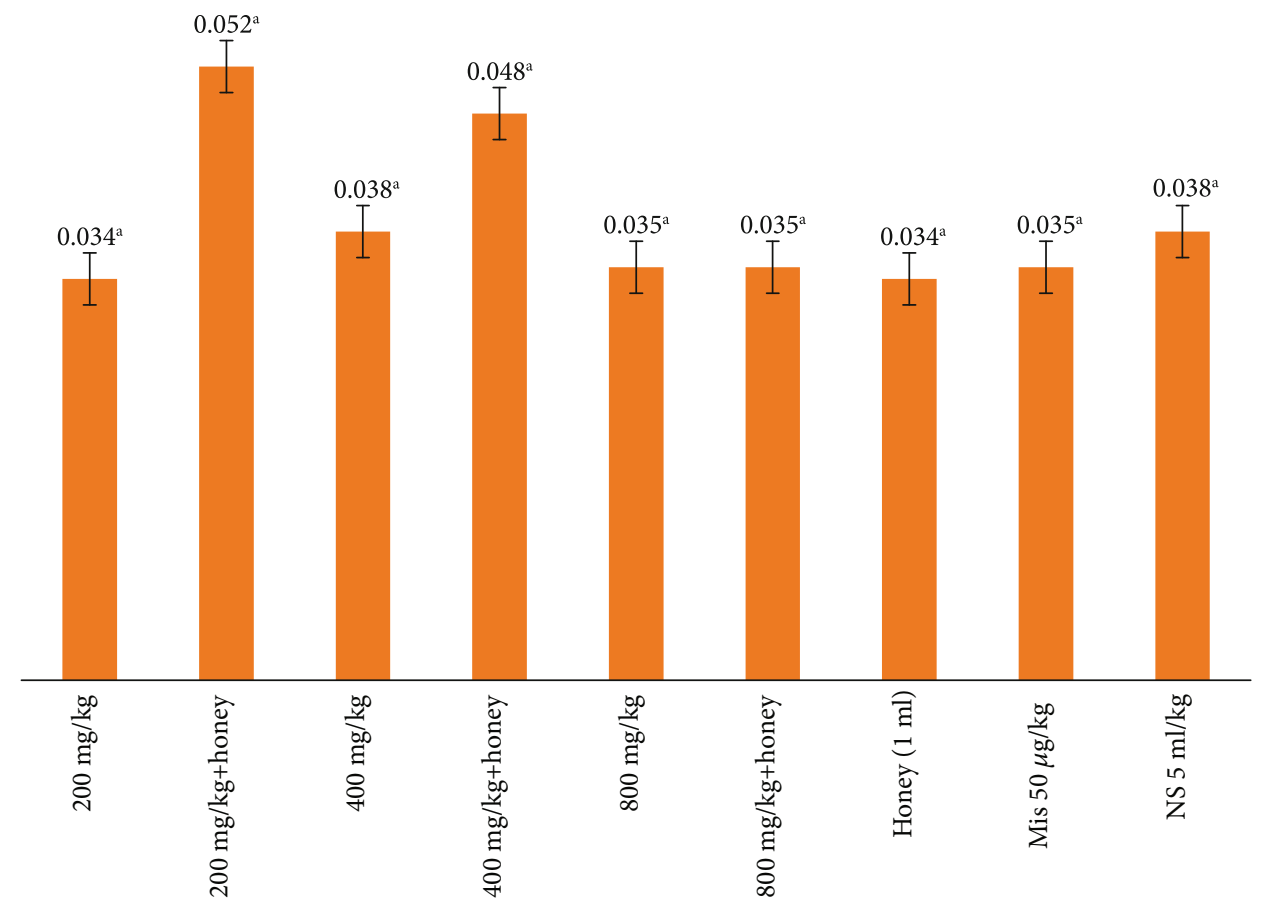

FIgURE 4: Effect of crude extract of E. hirta combined with honey on the stomach gastric mucus of rats using $0.6 \mathrm{M} \mathrm{HCl}$.

formation or inhibition of mucus synthesis and also lipid peroxidation. The gastric ulcer induced by $0.6 \mathrm{~mol} / \mathrm{l} \mathrm{HCl}$ could be associated with the increased purine degradation that leads to increased $\mathrm{O}_{2}{ }^{-}$radical production and ROSmediated increased lipid peroxidation. A low level of mucus suggests that the integrity of gastrointestinal apparatus was impaired when exposed to $0.6 \mathrm{~mol} / \mathrm{l} \mathrm{HCl}$ as seen in the negative control group. Treatment with the methanol leaf extract of E. hirta and the combination with honey showed that there was significant reduction in the ulcer index, most notably in the treatment with a combination of the extract and honey.

The antiulcer effect of $E$. hirta combined with honey could be attributed to antioxidant and free radical scavenging effect of the phytoconstituents of E. hirta and honey, respectively, as reported by several studies $[25,26]$. Thus, the 
antioxidant effect of honey was due to its catalase content [25], and one molecule of catalase can scavenge for 40 million free radicals [26]. The antiulcer effect could have resulted from the cytoprotective effect of E. hirta combined with honey, which could be due to increase in mucus secretion that protects the gastric mucosal membrane from corrosive effects of $\mathrm{HCl}$ and stomach acid overproduction. This result is in agreement to the findings of [27] who reported that ethanolic extract Euphorbia hirta possesses gastroprotective potential which is related partly to preservation of gastric mucus secretion and antisecretory action. Also, the findings are similar to the findings of Mahmood et al. who reported that honey in combination with Trigonella foenum-graecum seed has antiulcer potential [13].

The combination of crude extract of E hirta and honey showed increased inhibition of ulceration, and this implied that there is synergy in activity. Flavonoids in E. hirta and catalase in honey by their capacity as a free radical scavenger [28] and saponins by their capacity to produce mucus could protect the gastric mucosal membrane against the acid effects and could synergistically be responsible for the antiulcer effect of these combinations.

Flavonoids enhance the protection of the gastric mucus therefore inhibiting ulceration. They stimulate prostaglandin bicarbonate and mucus secretion and prevent degrading effects of reactive oxidants in the gastrointestinal system [29]. Flavonoids have also been reported to offer protection in ulcer development by increasing capillary resistance and improving microcirculation [30]. It is acknowledged that tannins protect the outermost layer of the mucosa and make it less permeable and more resistant to chemicals and mechanical injury or irritation and thus prevent ulcer development [30]. Saponins induce mucus production, which protects the gastric mucosal membrane against the acid effects [31].

This finding further supports the veracity of the indigenous knowledge ethnomedicinal claim and has shown that E. hirta combined with honey is relatively safe for consumption since its $\mathrm{LD}_{50}$ exceeded $5000 \mathrm{mg} / \mathrm{kg}$ and also posses gastroprotective and gastrotherapeutic effect.

\section{Conclusion}

The result of this study suggests that the methanolic extract of E. hirta combined with honey is safe for use and could protect the gastric mucosa against damage by $\mathrm{HCl}$ and also has ulcer healing effect. The study confirmed that crude extract of E. hirta and standard drugs produced a decreased ulcer index and increased percentage inhibition of ulceration in $0.6 \mathrm{~mol} / \mathrm{l} \mathrm{HCl}$-induced ulceration. Furthermore, the E. hirta crude leaf extract at $200 \mathrm{mg} / \mathrm{kg}$ combined with honey had more gastric mucus concentration which implied that the combination has an enhanced and synergistic effect against $0.6 \mathrm{~mol} / \mathrm{l} \mathrm{HCl}$-induced ulceration in rats. The ulcer inhibition potential of E. hirta combined with honey could justify the use of this combination by the Igbo traditional healers in Southeastern Nigeria for the treatment of ulcer.

\section{Data Availability}

Data supporting the research findings are available in this manuscript, and any other information required shall be supplied based on request.

\section{Conflicts of Interest}

The authors declare that there is no conflict of interest.

\section{Authors' Contributions}

All authors contributed to the conceptualization, formal analysis, investigation, methodology, supervision, and writing of the manuscript.

\section{References}

[1] K. Harold, D. M. Grant, and J. Mitchel, Principles of medical pharmacology, Seventh Ed, Elsevier Canada Ltd, 2007.

[2] K. Ramakrishnam and R. C. Salinas, "Peptic ulcer diseases," Journal of American Family Physician, vol. 76, pp. 10051012, 2007.

[3] S. Kumar, R. Malhotra, and D. Kumar, "Euphorbia hirta: its chemistry, traditional and medicinal uses, and pharmacological activities," Pharmacognosy Reviews, vol. 4, no. 7, pp. 58-61, 2010.

[4] M. A. B. Rajeh, Z. Zuraini, S. Sasidharan, L. Y. Latha, and S. Amutha, "Assessment of Euphorbia hirta L. leaf, flower, stem and root extracts for their antibacterial and antifungal activity and brine shrimp lethality," Molecules, vol. 15, no. 9, pp. 6008-6018, 2010.

[5] J. N. Ogbulie, C. C. Ogueke, I. C. Okoli, and B. N. Anyanwu, "Antibacterial activities and toxicological potentials of crude ethanolic extracts of Euphorbia hirta," African Journal of Biotechnology, vol. 6, pp. 1544-1548, 2007.

[6] A. Gyuris, L. Szlavik, J. Minarovits, A. Vasas, J. Molnar, and J. Hohmann, "Antiviral activities of extracts of Euphorbia hirta L. against HIV-1, HIV-2 and SIV mac251 $_{1}$ " In vivo International Journal of Experimental and Clinical Pathophysiology and Drug Research, vol. 23, no. 3, pp. 429-432, 2009.

[7] L. Tona, K. Kambu, N. Ngimbi et al., "Antiamoebic and spasmolytic activities of extracts from some Antidiarrhoeal traditional preparations used in Kinshasa, Congo," Phytomedicine, vol. 7, no. 1, pp. 31-38, 2000.

[8] P. Dass, S. Mekap, S. Pani, R. Sethi, and P. Nayak, "Pharmacological evaluation of anti-inflammatory activities of Euphorbia hirta against carrageenan induced paw-edema in rats," Der Pharmacia Lettre, vol. 2, no. 2, pp. 151-154, 2010.

[9] S. Mohamed, S. Saka, S. H. El-Sharkawy, A. M. Ali, and S. Muid, "Antimycotic screening of 58 Malaysian plants against plant pathogens," Pesticide Science, vol. 47, no. 3, pp. 259-264, 1996.

[10] P. C. Molan, "Potential of honey in the treatment of wounds and burns," American Journal of Clinical Dermatology, vol. 2, no. 1, pp. 13-19, 2001.

[11] J. S. Boateng, K. H. Matthews, N. E. S. Howard, and G. M. Eccleston, "Wound healing dressings and drug delivery systems: a review," Journal of Pharmaceutical Sciences, vol. 97, no. 8, pp. 2892-2923, 2008. 
[12] D. P. Mohapatra, V. Thakur, and S. K. Brar, "Antibacterial efficacy of raw and processed honey," Biotechnology Research International, vol. 2011, Article ID 917505, 6 pages, 2011.

[13] A. A. Mahmood, K. Sidik, and I. Salmah, "Anti-ulcer and gastro protective effects of honey in combination with Trignonella foenum graecum seed extract on experimental gastric ulcer in rats," International Journal of Molecular Medicine and Advance Sciences, vol. 1, pp. 225-229, 2005.

[14] M. Zimmerman, "Ethical guidelines for investigations of experimental pain in conscious animals," Pain, vol. 16, no. 2, pp. 109-110, 1983.

[15] L. T. D. Pfizer Pharmaceuticals, "Cytotec misoprostol : patients information," 2012, http://www.labelingpfizer.com.

[16] G. E. Trease and W. C. Evans, A Textbook of Pharmacognosy, Bailliere Tinall Ltd London, 13th edition, 1989.

[17] D. Lorke, "A new approach to practical acute toxicity testing," Archives of Toxicology, vol. 54, no. 4, pp. 279-287, 1983.

[18] S. S. Deshpande, G. B. Shah, and N. S. Parmar, "Anti-ulcer activities of Tephrosia purpurea in rats," Indian Journal of Pharmacology, vol. 35, no. 3, pp. 168-172, 2003.

[19] Z. Scepovic and B. Z. Radmanovic, "Interaction between reserpine and non-steroidal anti-inflammatory agents in producing gastric ulcers in rats," European Journal of Pharmacology, vol. 98, no. 3-4, pp. 445-448, 1984.

[20] S. J. Corne, S. M. Morrissey, and R. J. Wood, "A method for quantitative estimation of gastric barriers mucus," Journal of Physiology, vol. 242, pp. 116-117, 1974.

[21] P. V. Tan, N. G. Nditafon, M. P. Yewah, T. Dimo, and F. J. Ayafor, "Eremomastax speciosa: effects of leaf aqueous extract on ulcer formation and gastric secretion in rats," Journal of Ethnopharmacology, vol. 54, no. 2-3, pp. 139-142, 1996.

[22] I. P. Onyeka, M. M. Suleiman, and S. P. Bako, "Toxicity effects of methanolic extract of Euphorbia hirta-honey mixture in albino rats," Journal of Pharmacognosy and Natural Product, vol. 4, p. 147, 2018

[23] M. N. H. Daud, Phytochemical Analysis and Biological Activities of Euphorbia Hirta and Phyllanthus Watsonii, Universiti Putra Malaysia Institutional Repository, 2006.

[24] B. P. Sandeep and S. M. Chandrakant, "Phytochemical investigation and antitumour activities of Eurphobia hirta Linn," European Journal of Experimental Biology, vol. 1, no. 1, pp. 51-56, 2011.

[25] A. T. M. Mobarok Ali and A. O. al-Swayeh, "Natural honey prevents ethanol-induced increased vascular permeability changes in the rat stomach," Journal of Ethnopharmacology, vol. 55, no. 3, pp. 231-238, 1997.

[26] F. Edward, "The Health benefit of catalase. Global healing Centre: nature health and organic living," 2013, May 2020, http://www.globalhealingcentre.com.

[27] K. Rathnakumar, R. Verma, S. Jaikumar, and S. Sengottuvelu, "Antiulcer activity of Euphorbia Hirta against experimentally induced ulcer in rats," International Journal of Pharmaceutical, Biological and Chemical Sciences, vol. 2, no. 3, pp. 16-20, 2013.

[28] F. Borrelli and A. A. Izzo, "The plant kingdom as a source of anti-ulcer remedies," Phototherapy Research, vol. 14, no. 8, pp. 581-591, 2000.

[29] N. L. Dashputre and N. S. Naikwade, "Evaluation of anti-ulcer activity of methanolic extract of Abutilon indicum Linn leaves in experimental rats," International Journal of Pharmaceutical Sciences and Drug Research, vol. 3, no. 2, pp. 97-100, 2011.
[30] S. Sumbul, M. A. Ahmad, A. Mohd, and A. Mohd, "Role of phenolic compounds in peptic ulcer: an overview," Journal of Pharmacy and Bioallied Sciences, vol. 3, no. 3, pp. 361-367, 2011.

[31] C. N. Aguwa and C. O. Okunji, "Gastrointestinal studies of Pyrenacantha staudtii leaf extracts," Journal of Ethnopharmacology, vol. 15, no. 1, pp. 45-55, 1986. 